\title{
Do specimens attributed to Lystrosaurus murrayi \\ and $L$. declivis (Triassic Therapsida) represent one species?
}

AUTHOR:

J. Francis Thackeray ${ }^{1}$

\section{AFFILIATION:}

${ }^{1}$ Evolutionary Studies Institute, School of Geosciences, University of the Witwatersrand, Johannesburg, South Africa

\section{CORRESPONDENCE TO: \\ Francis Thackeray}

EMAIL:

francis.thackeray@wits.ac.za

\section{KEYWORDS:}

holotypes; dicynodont; conspecific; Lystrosaurus; therapsid

\section{HOW TO CITE:}

Thackeray JF. Do specimens attributed to Lystrosaurus murrayi and L. declivis (Triassic Therapsida) represent one species? S Afr J Sci. 2018;114(3/4), Art. \#a0258, 2 pages. http://dx.doi. org/10.17159/sajs.2018/a0258

\section{PUBLISHED:}

27 Mar. 2018 (c) 2018. The Author(s). Published under a Creative Commons Attribution Licence.
Lystrosaurus murrayi and $L$. declivis are two dicynodont (Therapsida, or mammal-like reptile) species commonly represented in Triassic deposits which are referred to as the 'Lystrosaurus Assemblage Zone' of the South African Karoo, postdating the Permo-Triassic boundary at 252 million years ago. The holotypes of these two species are curated in the Natural History Museum in London. Unfortunately, both are fragmentary (personal observation). Despite the fragmentary condition of the holotypes, Cluver ${ }^{1}$, Cluver and King $^{2}$ and Brink ${ }^{3}$ accepted the view that at least two species of Lystrosaurus (L. murrayi and $L$. declivis) could be distinguished.

Lystrosaurus murrayi was first described by Thomas Henry Huxley in 1859. A year later, Richard Owen described a similar specimen as L. declivis. Recognising similarities in the two holotypes, Broom ${ }^{4}$ regarded Owen's specimen as 'probably' representing the same species as that which was described by Huxley in 1859. This view is consistent with those of Thackeray et al. ${ }^{5}$ By contrast, Botha-Brink et al. ${ }^{6}$ retain the view that two Triassic taxa of Lystrosaurus can be distinguished. In an impressive study, they examined as many as 97 crania attributed by them to $L$. murrayi, and 99 crania attributed to $L$. declivis. ${ }^{6}$

\section{Two hypotheses}

Thackeray's hypothesis addressed in this paper $\left(\mathrm{H}_{T}\right)$ is that specimens attributed to one or other of the two Triassic species are conspecific. $\mathrm{H}_{B B}$ is the alternative hypothesis (reflected for example by Botha-Brink et al. ${ }^{6}$ ) which is that two distinct Triassic species of Lystrosaurus can be recognised.

In order to test these two hypotheses, attention was given to the maximum basal skull length (BSL) dimensions in a total of 196 specimens of Lystrosaurus in Triassic deposits. ${ }^{6}$ Two other species of Lystrosaurus (L. maccaigi and $L$. curvatus), both of which occur in Permian deposits, were not considered here but deserve attention in future studies.

A summary of measurements obtained for BSL for specimens examined by Botha-Brink et al. ${ }^{6}$ and attributed by them to two Triassic species of Lystrosaurus, is given in Table 1. The results presented in Table 1 can be used to determine whether $\mathrm{H}_{\mathrm{T}}$ is supported.

Table 1: $\quad$ Comparison of basal skull length measurements for Lystrosaurus murrayi and L. declivis

\begin{tabular}{l|c|c}
\hline \hline & Lystrosaurus murrayi & Lystrosaurus declivis \\
\hline Number of crania & 97 & 99 \\
\hline Mean basal skull length $(\mathrm{mm})$ & 106.7 & 118.1 \\
\hline Standard deviation & 31.1 & 30.0 \\
\hline Coefficient of variation & 29.1 & 25.2 \\
\hline
\end{tabular}

From Table 1, the following observations are made:

1. The mean BSL dimensions in specimens attributed to $L$. murrayi $(106.7 \mathrm{~mm})$ is only slightly smaller than that for specimens attributed to $L$. declivis (118.1 mm).

2. The means are not significantly different (Students $t$-test, $p=0.05$ ).

3. The standard deviations are almost identical (31.1 and $30.0 \mathrm{~mm})$.

4. The coefficients of variation are almost identical (29.1 and 25.2).

Two important additional observations are:

5. Specimens attributed to the two species are both represented in the Lystrosaurus Assemblage Zone, with L. declivis apparently occurring only slightly later than L. murrayi, which apparently occurs first at the time of the Permo-Triassic boundary, 252 million years ago. ${ }^{6}$ Notably, the specimens are coeval in most of the Lystrosaurus Assemblage Zone.

6. Specimens attributed to $L$. murrayi and $L$. declivis both display an 'early breeding pattern', which is associated with relatively low percentages of large individuals in the Lystrosaurus assemblages in Triassic deposits. ${ }^{6}$

It can be concluded that $H_{T}$ is supported by all six of these observations.

Further analyses should be undertaken on measurements in addition to BSL to test $H_{T}$, using a morphometric analysis of the kind developed by Thackeray et al. ${ }^{7}$, updated by Thackeray ${ }^{8}$ and discussed by Thackeray and Schrein ${ }^{9}$ in the context of a probabilistic definition of a species, related to sigma taxonomy ${ }^{10,11}$, as opposed to 
the general tendency to use alpha taxonomy ${ }^{12}$ whereby specimens are classified in terms of discrete taxa, assuming clear boundaries between them.

The six observations presented here, in support of $\mathrm{H}_{\mathrm{T}}$, are consistent with the view held by Broom ${ }^{4}$ who stated that Owen's specimen attributed by him to $L$. declivis was 'probably' the same species represented by the holotype of $L$. murrayi described by Huxley in 1859 . The six observations presented here are also consistent with those of Cosgriff et al..$^{13}$

Thackeray et al. ${ }^{5}$ suggested that much of the variability in specimens attributed to $L$. murrayi and $L$. declivis may be a result of sexual dimorphism (associated in part with 'bossing' on crania above the orbits), or ontogeny within one species. It was indicated that bosses were likely to occur primarily in male specimens, as reflected by the following statement: 'Where supraorbital bosses are present, these occur mainly in relatively large individuals. We consider the presence of supraorbital bosses in almost $50 \%$ of large individuals and the absence of such bosses in about $50 \%$ of similar-sized individuals attributed to the same species, as a potential indication of differences between adult males and females's.

If only one species of Lystrosaurus species is represented in Triassic deposits of the South African Karoo, as hypothesised through $\mathrm{H}_{\mathrm{T}}$, the nomen 'murrayi' would have precedence over 'declivis' according to rules of nomenclature, as Huxley's specimen was described in 1859, a year earlier than that reported formally by Owen. A possibility to be considered is that $L$. murrayi and $L$. declivis are components within a chronospecies, recognising also the importance of hybridisation in a diversity of modern taxa. ${ }^{9}$

\section{Acknowledgements}

The National Research Foundation, the DST-NRF Centre of Excellence and the Andrew W. Mellon Foundation are acknowledged for their support. Jennifer Botha-Brink kindly facilitated access to measurements of specimens analysed by her and her colleagues. Angela Milner provided access to holotypes of Lystrosaurus at the Natural History Museum in London. Sir Andrew Huxley (grandson of T.H. Huxley) gave encouraging comments when the holotypes were examined.

\section{References}

1. Cluver MA. The cranial morphology of the dicynodont genus Lystrosaurus. Ann S Afr Mus. 1971;56(5):155-274.

2. Cluver MA, King GM. A re-assessment of the relationships of Permian Dicynodontia (Reptilia, Therapsida) and a new classification of dicynodonts. Ann S Afr Mus. 1983;91(3):195-273.

3. Brink AA. Illustrated bibliographical catalogue of the Synapsida. Handbook 10, Part I. Pretoria: Government Printer; 1982.

4. Broom R. The mammal-like reptiles of South Africa and the origin of mammals. London: Witherby; 1932. p. 244.

5. Thackeray JF, Durand JF, Meyer L. Morphometric analysis of South African dicynodonts attributed to Lystrosaurus murrayi (Huxley, 1859) and L. declivis (Owen, 1860): Probabilities of conspecificity. Ann Transv Mus. 1998;36:413420.

6. Botha-Brink J, Codron D, Huttenlocker AK, Angielczyk KD, Rutas M. Breeding young as a survival strategy during earth's greatest mass extinction. Sci Rep. 2016;6, Art. \#24053. https://doi.org/10.1038/srep24053

7. Thackeray JF, Bellamy CL, Bellars D, Bronner G, Bronner L, Chimimba C, et al. Probabilities of conspecificity: Application of a morphometric technique to modern taxa and fossil specimens attributed to Australopithecus and Homo. S Afr J Sci. 1997:93:195-196.

8. Thackeray JF. Approximation of a biological species constant? S Afr J Sci. 2007;103:489.

9. Thackeray JF, Schrein CM. A probabilistic definition of a species, fuzzy boundaries and 'sigma taxonomy'. S Afr J Sci. 2017;113(5/6), Art. \#0206, 2 pages. https://doi.org/10.17159/sajs.2017/a0206

10. Thackeray JF. Sigma taxonomy in relation to palaeoanthropology and the lack of clear boundaries between species. Proc Eur Soc Stud Hum Evol. 2015:4:220.

11. Thackeray JF. Homo habilis and Australopithecus africanus, in the context of a chronospecies and climatic change. Palaeoecol Afr. 2016;33:53-58.

12. Mayr E, Linsley EG, Usinger RL. Methods and principles of systematic zoology. New York: McGraw-Hill; 1953.

13. Cosgriff, JW, Hammer WR, Ryan WJ. The Pangaean reptile, Lystrosaurus maccaigi, in the Lower Triassic of Antarctica. J Paleontol. 1982;56(2):371-385. 